\title{
The modified Kansei Engineering-based application for sustainable service design
}

\author{
Markus Hartono \\ Department of Industrial Engineering, University of Surabaya, Indonesia
}

\section{A R T I C L E I N F O}

\section{Keywords:}

Kansei engineering

Kano model

TRIZ

Sustainability

Airport services

\begin{abstract}
A B S T R A C T
Considering the human-centered design, this paper shows a modified-integrated approach of how to quantify the impact of perceived Kano's attractive services on perceived emotional satisfaction (Kansei), followed by the formulation of innovative ideas for sustainable services using TRIZ (known as Theory of Inventive Problem Solving). The Kano's attractive service attribute is deemed to be a significant emotional booster (known as Kansei). Kansei Engineering (KE) is used to highlight the level of customer emotional satisfaction due to perceived service offerings. For the past seven years, there has been a rapid concern in Kansei Engineering (KE) in services. However, previous research of KE has mainly focused on the improvement and analysis of general service domains. There is little attention to sustainable services. Hence, this study provides a modified KE-based approach and aims to understand and satisfy customer emotional needs (Kansei) considering the social, environmental and economic performance. An empirical study in an international airport lounge and lobby services was conducted to confirm the applicability of the proposed model. Purposive sampling through in-depthinterview and face-to-face questionnaires which involved 100 valid subjects was used. Theoretically, these studies show the importance of Kansei's role in sustainable service development, highlighting more innovative and breakthrough solutions with less contradiction and "true-meaning" of Kansei. Practically, it provides a guideline for service designer and manager in identifying which attractive-based service attributes need to be prioritized considering Kansei satisfaction.
\end{abstract}

\section{Introduction}

The understanding of customer need followed by the match between customer expectation and perception in product and service experience becomes a significant challenge for ergonomists, product and service designer and manager. In the context of human need and satisfaction, ergonomics plays an important role. Traditionally, ergonomics deals with human capability and limitation, which is mainly focused on efficiency, effectiveness, and productivity (Grandjean, 1980). Once a working system is effectively and efficiently built, it promotes a significant level of productivity. Taking sustainability into account as the current trend for product and service interaction, ergonomics should put more effort into environmental and social performance (Dekker et al., 2013). Moreover, it promotes the optimal use of resources and maintains comfort for users.

In obtaining sustainable performance, however, there is a critical challenge on ergonomics for product and service design, which is to capture the unexpressed user need. It is also known as the unspoken/ hidden needs or the voice of the customer. Inherently, it is something highly important and sensitive for users or customers; once it is fulfilled it may lead to significant satisfaction and loyalty. However, it is not easy to dig and capture what the customer wants, as well as to translate it into product or service design elements. Kano et al. (1984) have introduced an attractive performance for product and service, namely attractive or delighter, which is dealing with something beyond customer satisfaction, yet it is not compulsory. Nagamachi and Lokman (2010) argued that the unspoken customer need is closely related to emotional satisfaction (or it is known as Kansei in Japanese).

In a broader context of sustainability and ergonomics, Manuaba (2007) has proposed a sustainability issue in ergonomics discipline. There are six criteria used in understanding ergonomics-approach for both product or service design, i.e., technical, economic, social, cultural, environmental, and energy-saving. One thing which is highlighted is that ergonomic should be economical. Apart from cognition and usability issues, service design should not overlook the affective process or emotional response. According to Rasamoelina et al. (2013), affect or emotion is related to the environmental issue. In other words, inversely, it is said that emotional response can be improved even more once a

E-mail address: markus@staff.ubaya.ac.id. 
product or service is fully designed incorporating environmental concerns. Surely, environmental awareness is a part of the sustainability dimension.

Emotions show a significant role in promoting more customer satisfaction and loyalty both in product and service experience (Hartono and Raharjo, 2015). Broadly, Kansei Engineering (KE) has been applied to model the interaction between emotions (known as Kansei) and product/service attributes (Nagamachi, 1995; Hartono and Tan, 2011). This method has several benefits as follows, but not limited to. Firstly, it promotes flexibility of use, given a specific context. For example, KE can model the perceived services and emotions, held in many service sectors (see Hartono and Tan, 2011; Hartono et al., 2013; Hartono, 2016). Secondly, according to Nagamachi (1995), this method is a powerful product design and development methodology considering user emotional needs. More specifically, concrete physical characteristics of the product will be generated, given Kansei's needs. Thirdly, KE can strengthen the existing quality methods, such as SERVQUAL and Kano model (Hartono and Tan, 2011; Llinares and Page, 2011; Hartono et al., 2013), Quality Function Deployment (QFD) or House of Quality (HoQ) (Hartono et al., 2013, 2017), and TRIZ (known as Theory of Inventive Problem Solving) (Hartono, 2016). In a recent study, this KE methodology has been applied in logistics services (Hartono et al., 2017). However, KE-based linear modeling is potentially lacking in understanding the "true meaning" of Kansei, which is a mismatch between perceived service attributes and Kansei. For example, a study by Hartono on 3 PL (third-party logistics) services company (2017) shows the Kansei "friendliness" was significantly statistically influenced by the perceived service attributes of "the display of application software" and "the delivery speed for goods and documents". Since there was a potential mismatch, this Kansei "friendliness" has been confirmed involving the management and customers of the company. The Kansei "friendliness" can be interpreted as how the company is closed enough to its customers. The ease of use and learnability of human-centered objects such as websites and application software should be encouraged. However, "the delivery speed for goods and documents" was questioned. It was supposed to be related to different Kansei words.

Since the 1980s-1990s, research of KE has been mainly on physical product design and development. Due to rapid growth in the service sector, KE methodology has been used to model and analyze the interaction between customer emotional needs and perceived service quality. According to Hartono and Tan (2011), the Kano model has a superiority to dig the bottom layer of customer needs, which are known as latent needs. They are closely connected to customer delight and emotions. Kano model enhances the KE methodology in terms of the supporting tool to map out the performance level of service attributes based on customer impression, as shown in Fig. 1. However, the Kano model lacks the understanding of which service attributes are significantly critical to a certain Kansei (Hartono et al., 2017). According to Hartono et al. (2017), recent research on KE in services has put Quality Function Deployment (QFD) methodology to finalize the priority for service improvement strategies.

As a growing business in today's economy, research on the service industry is highly required. Once there is an interaction between user and product, or customer and service (known as human-system interaction), KE can contribute to. In Kansei Quality Management (KQM), service is of high quality once it makes a good impression and longlasting emotional bondage to customers (Nagamachi and Lokman, 2010). Through the integration of relevant quality tools and KE methodology, research on $\mathrm{KE}$ in services is relatively less explored. In the recent research, the service domains in $\mathrm{KE}$ study are limited to general service improvement and strategies, such as hotel services, restaurant services, and IT-based logistics services (Hartono et al., 2017). Due to

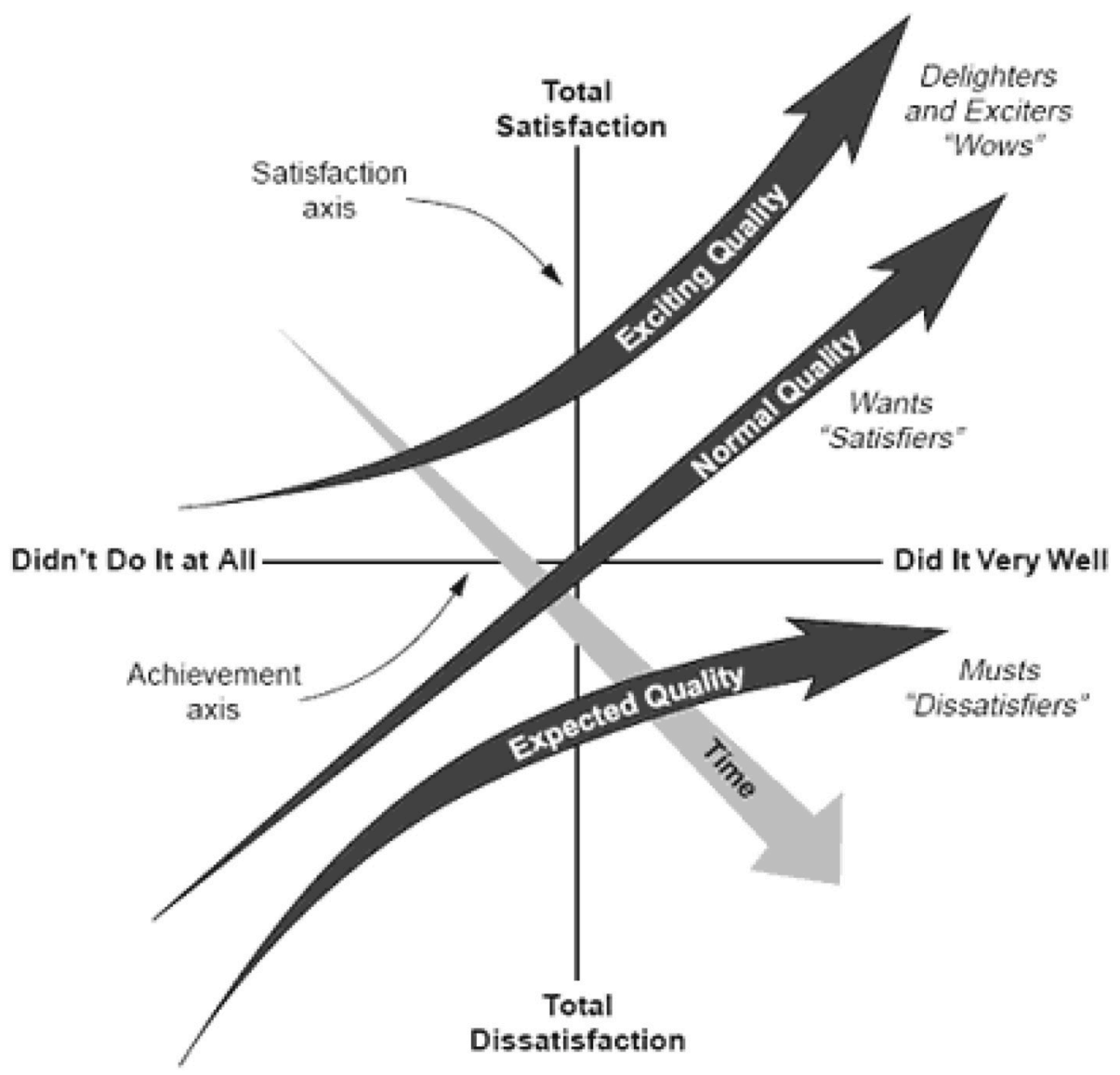

Fig. 1. Three main categories of Kano (ReVelle, 2004). 
the significant growth of the service industry in both global and Indonesia, more research on Kansei on services is highly expected.

This study takes the opportunity to modify the model of KE integrated with the Kano model and the Theory of Inventive Problem Solving (known as TRIZ) (Altshuller, 1997) considering the 'true meaning', applied to sustainable services. TRIZ is expected to tackle the potential weakness of the use of QFD in generating improvement ideas. This tool can generate improvement ideas and strategies with less possible contradiction (Chai et al., 2005). The 'true meaning' is called a KE-based confirmatory approach, i.e., a mechanism to confirm the linear model of Kansei as a function of perceived service attributes. The perceived service attributes may have been questioned to represent certain Kansei. Consolidation is required to confirm the appropriateness of Kansei's impact on service attributes.

Hence, the integrative model of KE, Kano, and TRIZ considering confirmatory approach is hoped to provide detailed steps for operational use, novelty, and focus not only on what is commonly known. Along with the increase of market competition in service industries, KE has a significant potential to contribute to service development and improvement considering emotional needs. The principle of sustainability is proposed into this integrated framework as a new concern on service design and development. Sustainable service is focused on the offerings which fulfill customer needs and bring the effort to the social and environmental performance as well. Ergonomics should be responsible for playing a significant role in global competitiveness, apart from its contribution to the quality of local content (Dekker et al., 2013). Though it is debatable, the potential benefit of sustainability practice in ergonomics is surely both for user or customer and designer or maker or producer. Tosi (2012) pointed out that the ergonomic approach which stresses the response to both expressed and latent customer needs followed by design innovation is highly needed.

Thus, the objectives of this study are two-fold. Firstly, this study is to modify and extend the integrative model of Kansei Engineering and the Kano model in sustainable services considering the TRIZ and confirmatory approach. Secondly, it is to test this modified integrative model incorporating an empirical study in an international airport lounge and lobby services. This paper is structured as follows. It describes the introduction as the first part and then followed by a literature review. Afterward, it provides research methodology, and then analysis and discussion. In the final section, this paper wraps up the conclusion and recommendations for further study.

\section{Literature review}

\subsection{SERVQUAL and Kansei}

According to Hartono (2016) and Hartono and Tan (2011), the 5 dimension-based of SERVQUAL's model as proposed by Parasuraman et al. (1988) is used as a representative of perceived service attributes and service gap between perceived and expected service offer. There are five common dimensions utilized, namely, (i) Tangible, (ii) Empathy, (iii) Responsiveness, (iv) Reliability, and (v) Assurance. These dimensions could be modified according to specific contexts, such as restaurants, hotels, and logistics. They serve as independent variables that influence emotional response (or known as Kansei in Japanese) (Hartono, 2016) as they are applied to product traits (Nagamachi, 1995). In other words, Kansei is defined as a function of perceived service quality. According to Wong (2004), perceived service quality has a positive impact on emotional satisfaction and impression and brings a significant influence on customer loyalty. What has been perceived by customers will serve as a cognition-based process that stimulates Kansei's response (Lin, 2004).

\subsection{Sustainable services and human factors}

Sustainable services should be directed into the understanding and interpretation of customer need and expectation. How to respond to the expressed and unexpressed customer needs is of challenging. In other words, when a service designer can fulfill and satisfy what is highly expected by customers, and then sustainable services can be achieved. Moreover, services that deliver and create happiness to the customers will be sustainable (Norman, 2004). According to Hartono et al. (2017), a sustainable service is related to innovation in serving and delivering serving offerings beyond usability and functionality. It is deemed to something satisfying customer emotional needs (or known as Kansei in Japanese) (Nagamachi and Lokman, 2010).

One of the focuses of innovative services is something that dealt with eco-efficient services. Eco-efficient services are categorized into 3 parts (Tukker and Tischner, 2006), namely, (i) product-based, (ii) user-oriented, and (iii) result-oriented. The result-oriented service category is found to have the highest eco-efficient potentials. The potential mismatch between customer needs and provider offerings is concerned as a result of eco-efficient service implementation.

Incorporating sustainability in Kansei-based service design and development promotes more increased operational efficiency and effectiveness on both provider and customer sides. Some studies have been conducted to promote the importance of sustainability in product and service design. A recent study by Sakao et al. (2019) has shown a modified Product-Service Systems (PSS) addressing the maximum value-in-use of product and service for both user and provider/manufacturer. PSS is a combined offering of products and services (a higher-level concept for offerings than products with a focus on value-in-use) which drives the potential for economic and environmental advantage. According to Sakao et al. (2009) and Sakao et al. (2019), the improved methodological approach of PSS which addresses the enhancement of value-in-use for both users and the provider has been applied at complex product manufacturers bringing benefits to all aspects of sustainability. It starts with the identification of customer requirements and experience and ends with proposed solutions promoting economic, environmental and social benefits. Inherently, it starts and ends with the customer. It includes analyzing the customer activities and requirements, segmenting and categorizing customers according to quality and cost requirements, extracting and prioritizing values including the social dimensions, enhancing values in terms of quality and cost, translating all values to product/service design parameters, generating improvement strategies, and investigating sustainability aspects (i.e., economic, environmental and social) on proposed strategies, and wrapping-up with design solutions. It shows that there is a screening process to fit what the customer requires to product/service design parameters considering quality, cost, environmental and social aspects.

Modern business practice emphasizes the social dimension equally as the environmental one. For an enterprise's lifecycle engineering practice, few insights are available on how to simultaneously consider the three dimensions of sustainability: economic, environmental, and social. Thus, developing an approach to consider the multiple dimensions of sustainability has been set as a goal of future research. A focus on services that extend the efficiency and value of products will support a more sustainable and profitable practice (Rothenberg, 2007). A new concept called servicizing (Rothenberg, 2007) has been proposed; it leads the suppliers and manufacturers to change their business focus from selling products to providing services. It turns the demand for reduced material use into a business strategy. Another definition of this concept is promoting a combination of products and services in which the customer satisfaction will be achieved by increasing the service component of a product offers. It is driven by the service and function that the product can deliver. An example of green practice and service sustainability is shown by Xerox. This company finds out that its offered services may promote both environmental and financial bottom lines. The challenge for today is material consumption related to environmental issues. Companies are challenged to help their customers achieve their expectations and goals while using fewer products.

A new challenge for the sustainability and the environment is about 
rapid urban expansion and economic development. A recent study on the energy and water resources regarding sustainability has been conducted (Nawab et al., 2019). It is to trace energy and water flows, starting from production to consumption perspectives in a multi-scale economic system. A concern on energy and water policies has been raised and driven by challenges such as resource access, environmental impact and specific national priorities (Chen et al., 2018).

Innovation in services should maintain the efficiency and effectiveness of resources. Efficiency discusses the minimum amount of resources (e.g., time, money, labor hours). Effectiveness tries to fulfill the deeper layer of customer needs, which is related to emotional-based needs. For sure, the quality of service should be well-maintained.

Using ergonomics in sustainable services is a big opportunity to explore. Inherently, both ergonomics and sustainability have a common concern about sociotechnical problems. Ergonomics puts much effort into exploring human capability and limitation in so complex environmental, economic and cultural systems. Hence, there is a big potential to integrate the two those disciplines, namely, ergonomics-based approaches for sustainable services. It means the purpose of sustainable service is not only to achieve optimum performance in terms of social and environmental sides but also how to fit user and worker needs.

\subsection{Kano model and TRIZ in Kansei Engineering for service design}

Ergonomics is concerned with human capability and limitations. At the product and service design, this discipline is expected to be a methodology for capturing the ideas of how to fulfill customer needs, followed by the assessment of the effectiveness of customer experience (Tosi, 2012). More specifically, this study takes Kansei Engineering into account as the main method for sustainable service design. In product and service design, Kansei Engineering provides a sophisticated methodology in exploring and capturing customer emotional needs and then being translated into product characteristics or service attributes.

According to Hartono and Tan (2011), the Kano model (Kano et al., 1984) strengthens the Kansei Engineering methodology by providing a screening-based step to identify which service attribute is critical to customer Kansei satisfaction. More specifically, Kano's attractive attribute (known as delighter) which leads to significant Kansei is prioritized (see Yang (2011); Hartono and Tan (2011) for the details of the Kano model in Kansei Engineering methodology). The improvement strategies to any service attributes which are more focusing on significant Kansei are then formulated.

Kansei moves beyond the usability, reliability, and functionality of products and services. Particularly, recent studies show that Kansei has brought its significance for service design and innovation (see Hartono and Tan, 2011; Hartono et al., 2013; Hartono, 2016; Hartono et al., 2017). Through its ergonomics-based methodology, known as Kansei Engineering, it provides an innovative ergonomics-based methodology capturing customer emotional needs and translating them into product and service characteristics (Nagamachi and Lokman, 2011). A generic methodology of Kansei Engineering is provided in Fig. 2. One of the strengths of this methodology is that compatibility to be engaged with quality management and statistical tools (see Hartono and Tan, 2011; Hartono, 2016).

Humans will evaluate the performance of services both cognitively and affectively. According to Khalid and Helander (2006), affect is more sensitive than cognition since it makes people judge something quickly. Affect deals with emotions, while cognition covers a wide range of knowledge, meaning, and belief. In the area of services, more recent research shows more emphasis on emotions and customer loyalty. Emotional satisfaction (known as Kansei as well) has been found highly correlated with perceived service quality and customer loyalty (Wong, 2004; Ladhari, 2009). Emotions/Kansei is a partial mediator of the impact of perception of service quality on customer loyalty (Hartono and Raharjo, 2015). Moreover, emotional satisfaction is proven as a good predictor of customer loyalty (Dixon et al., 2010). The emotion-based engineering methodology, which is Kansei Engineering (KE) has been extended to address more complex customer experience requirements in the design of product-service systems (PSS), taking a case study of new public transportation PSS concepts involving multidisciplinary design team (Carreira et al., 2013).

To formulate the ideas for improvement followed by calculating their importance level, the house of quality (HoQ) is usually used. However, the use of HoQ is often criticized due to possible contradictions between proposed solutions (Chai et al., 2005). Moreover, service designers and engineers may lack innovative ideas. They are bounded to the current and previous experience and the limit of available design methods or tools. To overcome this limitation, Chai et al. (2005), proposed TRIZ-based principles for service improvement as it has been modified from that of Altshuller (1997). TRIZ stands for Teoriya Resheniya Izobretatelskikh Zadach and is known as the Theory of Inventive Problem Solving (TIPS). TRIZ is regarded as a powerful methodology and basis for creative innovation (Chai et al., 2005), adopting the universal principles of invention and patent. Like HoQ, other idea-generating methods such as lead-user research, competitor analysis, and brainstorming depends on past experiences which may lead to unavoidable psychological inertia (Zeithaml and Bitner, 2000). Hence, creative and breakthrough-sound ideas may be blocked and neglected.

The typical TRIZ-based methodology for service design and improvement comprises at least three steps, namely, (i) problem definition, (ii) problem resolution, and (iii) evaluation of the proposed solution. TRIZ-based Kansei Engineering applied in services incorporating cultures, as summarized in Fig. 3.

According to Hartono (2016), in general, there are four stages, i.e., affective process (Kansei-based measurement), service attribute categorization, synthesis and modeling of perceived Kansei and service, and TRIZ-based service design and improvement. The TRIZ-based approach will perform the contradiction analysis, elimination, and ideal solution analysis. More specifically, this approach of Kansei Engineering is equipped with TRIZ to resolve the potential contradictions due to at least two conflicting characteristics required by a certain customer need.

It also has utilized Altshuller's TRIZ 40 inventive principles combined with 39 features of the contradiction matrix. Inherently, there are other principles used in TRIZ, such as the four separation principles and the algorithm of inventive problem solving (ARIZ), and 76 standard solutions. Due to more on intangible form, the existing TRIZ principles for the physical product have been modified for use in services (Zhang et al., 2003). Chai et al. (2005) have formulated a set of modified TRIZ-based principles for service design.

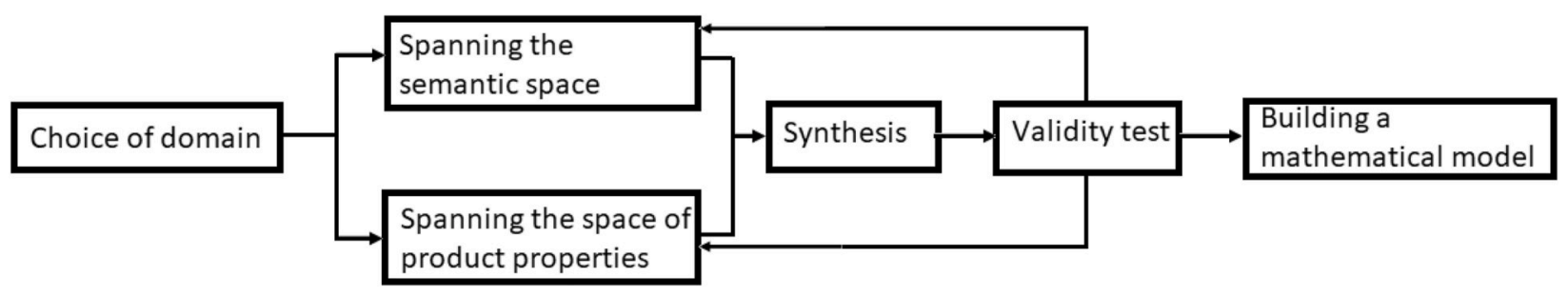

Fig. 2. General Kansei Engineering methodology (Schütte et al., 2004). 


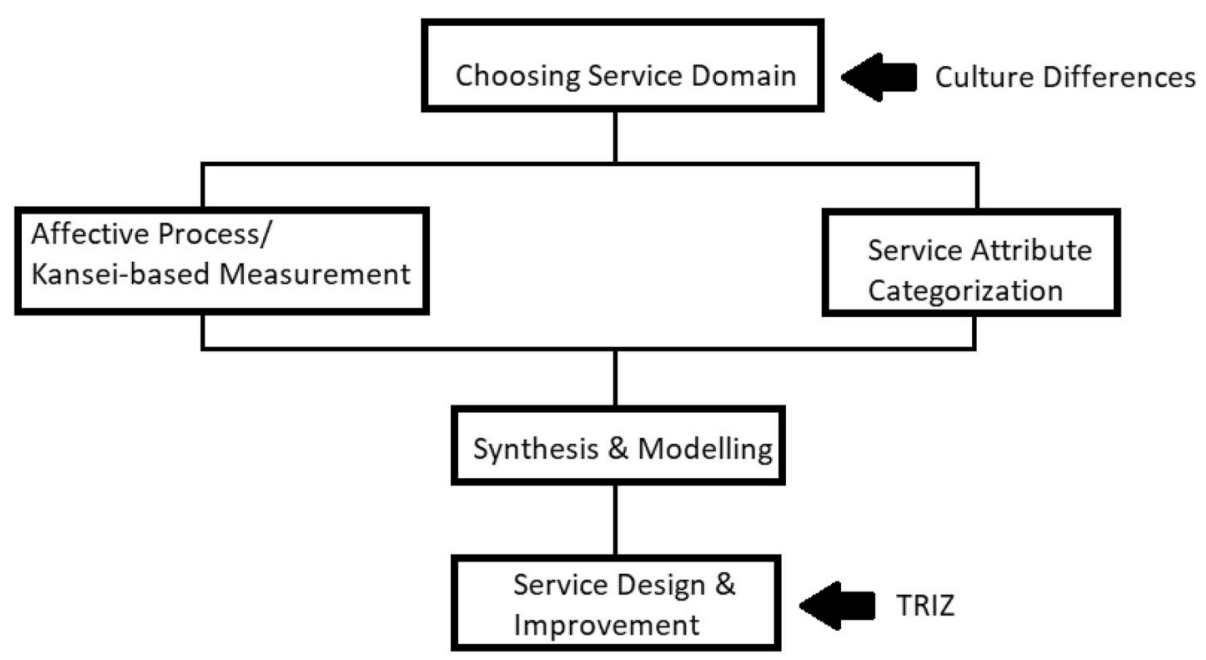

Fig. 3. Integrated TRIZ-Kansei Engineering approach in services (Hartono, 2016).

\subsection{Mapping of research on Kansei Engineering in services}

It refers to some studies of Kansei Engineering (KE) in services since 2011 and is summarized from Hartono et al. (2017). Apart from physical products, this summarizes KE research and finding highlights the importance of Kansei role in some service contexts or fields. It gives an insight that KE methodology can be enhanced by supporting quality and statistical tools. In addition to that, incorporation of the current issues will enrich the application scope of KE methodology. This current study of KE puts stress on sustainable services. Due to the complexity and fuzziness of customer emotional responses, the potential mismatch between perceived Kansei and perceived service attributes is highlighted. It is called a "KE-based confirmatory approach for the true meaning of Kansei". A matrix between the author(s) and relevant methods/tools are provided in Table 1 . It shows that research of KE in the field of sustainability is interesting (see Table 2).

This current study provides a modified model of Kansei Engineering applied to sustainable service which is proposed by incorporating sustainability and the confirmatory mechanism of Kansei linear model. It refines and modifies the previous relevant KE-based models by highlighting some potential improvements as follow:

\section{Modified KE-based model and empirical study}

\subsection{Modified KE-based application model for sustainable service design}

The concerns of "true meaning" of Kansei and sustainable service
Table 2

Opportunity to refine and modify the previous main research on Kansei in services.

\begin{tabular}{cll}
\hline $\begin{array}{l}\text { Main } \\
\text { references }\end{array}$ & Major findings & $\begin{array}{l}\text { Opportunity to refine and } \\
\text { modify }\end{array}$ \\
\hline $\begin{array}{c}\text { Hartono } \\
(2016)\end{array}$ & $\begin{array}{l}\text { Incorporation of innovative } \\
\text { contradiction-free solutions for } \\
\text { service attributes which are } \\
\text { sensitive to Kansei (i.e., emotional } \\
\text { satisfaction) considering culture } \\
\text { differences }\end{array}$ & $\begin{array}{l}\text { • Robustness of the proposed } \\
\text { solutions and strategies }\end{array}$ \\
& $\begin{array}{l}\text { Direct and less complicated } \\
\text { fulfillment of any low customer }\end{array}$ & - "The true meaning" of \\
Hartono & $\begin{array}{l}\text { Katisfied yet attractive logistics } \\
\text { et al. } \\
(2017)\end{array}$ & perceived service attributes \\
& $\begin{array}{l}\text { service attributes which are } \\
\text { critical to Kansei }\end{array}$ & \\
Hartono & $\begin{array}{l}\text { Integration of Kano and KE } \\
\text { methodologies in exploring the } \\
\text { (2018) }\end{array}$ & $\begin{array}{l}\text { public service attributes which are } \\
\text { sensitive to Kansei }\end{array}$ \\
\hline
\end{tabular}

design are regarded as the main priority, while the robustness of the proposed strategy is deemed to be the second one. Hence, the refined and modified KE-based application model for sustainable service design is provided in Fig. 4 below.

Inherently, it starts with the selection of the service domain. It may refer to a company that focuses more on services, but not limited to. A company that serves a bundle of goods and services is also considered.

Table 1

The current state of KE research in services (modified and extended from Hartono et al., 2017).

\begin{tabular}{|c|c|c|c|c|c|c|c|c|c|c|c|c|}
\hline \multirow[t]{3}{*}{ Author(s) } & \multicolumn{12}{|c|}{ Characteristics } \\
\hline & \multicolumn{6}{|c|}{ Approaches } & \multicolumn{4}{|l|}{ Fields } & \multicolumn{2}{|c|}{ Kansei Model } \\
\hline & General & SERVQUAL & Kano & TRIZ & QFD & Fuzzy & Culture & Logistics & Public & Sustainability & Linear & Confirmatory \\
\hline Llinares and Page (2011) & $\checkmark$ & & $\checkmark$ & & & & & & & & & \\
\hline Hartono and Tan (2011) & $\checkmark$ & $\checkmark$ & $\checkmark$ & & $\checkmark$ & & & & & & $\checkmark$ & \\
\hline Hartono (2012) & $\checkmark$ & $\checkmark$ & $\checkmark$ & & $\checkmark$ & & & & & & $\checkmark$ & \\
\hline Rasamoelina et al. (2013) & $\checkmark$ & & & & & & & & & & & \\
\hline Hartono et al. (2013) & $\checkmark$ & $\checkmark$ & $\checkmark$ & & $\checkmark$ & & $\checkmark$ & & & $\checkmark$ & $\checkmark$ & \\
\hline Hartono and Raharjo (2015) & $\checkmark$ & $\checkmark$ & $\checkmark$ & & & & $\checkmark$ & & & & & \\
\hline Chen et al. (2015) & $\checkmark$ & & & & & & & $\checkmark$ & & & & \\
\hline Hartono (2016) & $\checkmark$ & $\checkmark$ & $\checkmark$ & $\checkmark$ & & & $\checkmark$ & & & & $\checkmark$ & \\
\hline Hartono et al. (2017) & $\checkmark$ & $\checkmark$ & $\checkmark$ & & $\checkmark$ & & & $\checkmark$ & & & $\checkmark$ & \\
\hline Hartono et al. (2018) & $\checkmark$ & $\checkmark$ & $\checkmark$ & & & & & & $\checkmark$ & & $\checkmark$ & $\checkmark$ \\
\hline This current study & $\checkmark$ & $\checkmark$ & $\checkmark$ & $\checkmark$ & & & & $\checkmark$ & & $\checkmark$ & $\checkmark$ & $\checkmark$ \\
\hline
\end{tabular}

$\sqrt{ }$ remarks "relevant or associated with". 
Next, it continues to the measurement of Kansei response (known as the spanning of semantic space) and the measurement of perceived services utilizing the generic SERVQUAL model (known as the spanning of service attribute) of the targeted customers (Schütte et al., 2004; Hartono and Tan, 2011). The SERVQUAL dimensions by Parasuraman et al. (1988) will be modified according to the specific service context and setting and categorized into either Kano's attractive (A), one-dimensional $(\mathrm{O})$ or must-be $(\mathrm{M})$. In line with previous studies on Kansei Engineering in services, this research will put more effort into Kano's attractive (A) and one-dimensional (O) service attributes since they are significantly found to be stimuli to Kansei. Afterward, the "A" and "O" attributes are linked to each significant Kansei. It is to identify which service attributes are significantly impacting a certain Kansei, through a linear regression modeling. Then, the KE-based confirmatory approach is applied. It is to confirm whether the Kansei is truly represented by the perception of any related perceived service attributes. The description of factors influencing Kansei is introduced. It involves some experts and customers (stakeholders) to check the appropriateness of Kansei linear models.

The prioritized significant service attributes through weighing scales considering the Kano weight, the importance level of service attributes and service gaps (see Hartono, 2016; Hartono et al., 2017) are then connected to the formulation of improvement strategies using TRIZ methodology. The ergonomics-based sustainability dimensions are considered to categorize TRIZ-based solutions. The expected solutions are contradiction-free.

\subsection{Empirical study on airport lounge and lobby services}

This study took international airport services as an empirical case. The airport industry is increasing rapidly, especially in Indonesia, due to the national economic growth and open market in ASEAN (The Association of Southeast Asian Nations) region. Airport service is considered as one of the complex services as it involves passengers as the core customer, and other entities including employees, supporting staff, and merchants. Regarding global competition, customer satisfaction and comfort are of high interest, whereas the concern on sustainability elements, namely, environmental, social and economic will produce a more competitive advantage. In a deeper understanding of how to provide excellent services to the customer, it is highly required to identify the critical service attributes which are sensitive to Kansei and improve them considering the least contradiction among possible design characteristics.

Air transport is considered one of the prominent issues in the logistics business. The activities involved in airport services are widely ranged, starting from materials or goods movement to people mobility. The speedy delivery time, low or even no delay and enough air carriers are highly demanded. Moreover, the conveniences, friendliness of staff, cleanliness of airport and aircraft interior and fresh waiting room are deemed critical to customer impression. Both physically and emotionally, excellent service performance must be delivered to potential customers.

How to serve the customer better is a must. The background and rationale of airport service have been chosen. The international airport has been selected as a case study since there are many services attributes to fulfill customer needs such as waiting rooms, cafeteria, and friendliness of the staff. An international airport is deemed to be a complex enterprise made up of different services and systems of systems. It is a combination of tangible and intangible services, regarded as a fastgrowing service business in today's economy (Cotton, 2007). The international airport serves a wide range of worldwide people and things moving.

Over the past 10 years, Indonesia's business is booming. The rise of aviation service demand is driven by increasing tourism, international trade and the development of regional economic hubs. The number of airline passengers in Indonesia has been significantly increasing both domestic and international flights from 2008 to 2012 with an average growth of $9.46 \%$ per year (www.bps.go.id).

In the international airport service, it is critical to increase operational efficiency and minimize operational costs yet improve airport capacity. Passengers mostly expect short waiting times, quick baggage handling, and easy navigation through the airport. Besides, to strengthen the safety and security of travelers and cargo is of interest. In general, the goal is to enhance the quality of the passenger experience. In other words, international airport serves four crucial elements (Cotton, 2007), i.e., (i) physical, economic and social surrounding, and environment, (ii) movement of passengers and goods through its terminals, (iii) airlines and franchisees of commercial service, and (iv) a business generating place.

Incorporating human factors and ergonomics point of view, the concern of sustainability in the airport services is mainly related to the social dimension. It will start with customers, and end with customers as well. The airport services might include the attributes of public awareness and education, stakeholder relationships, passenger wellbeing, and employee wellbeing (Berry et al., 2008). Using the proposed integrative model, Kansei Engineering and Kano will address the identification and exploration of customer emotional needs (known as Kansei words) since it is more dominant than a cognitive process in the entire service experience. Afterward, those Kansei words will be translated into service design characteristics through the implementation of TRIZ which is to resolve the possible contradictions among them.

International airport service attributes have been generated and

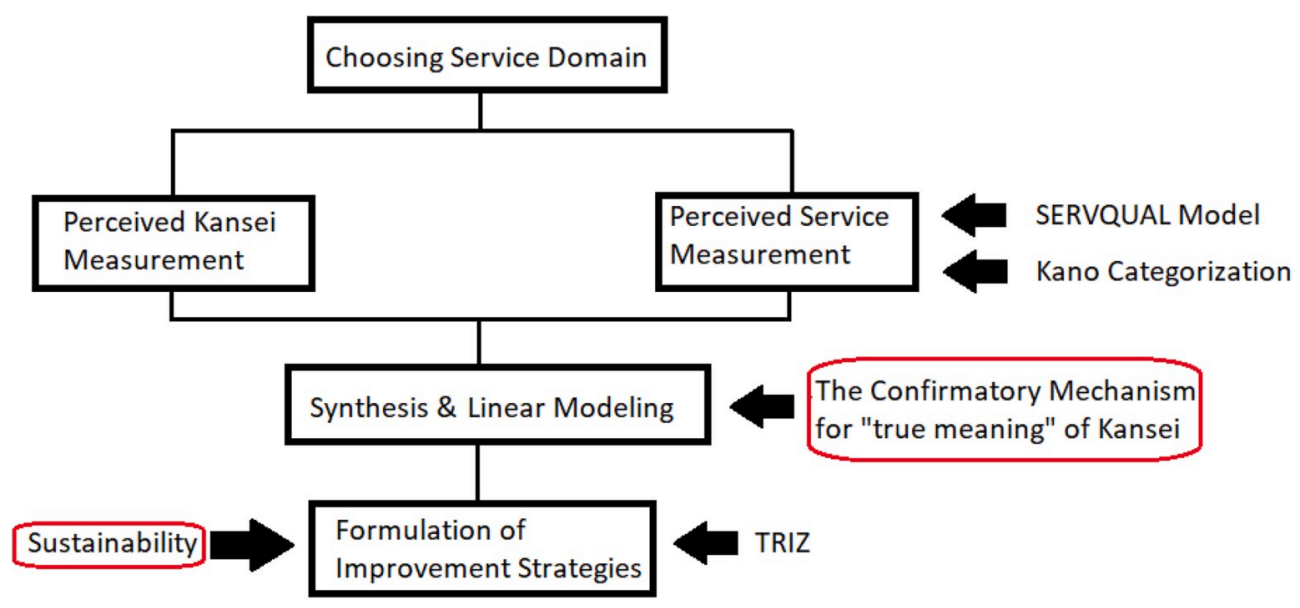

Fig. 4. The modified KE-based Application Model for Sustainable Service Design. 
modified from Parasuraman's twenty-two general SERVQUAL model (Parasuraman et al., 1988). The service domain of the airport has been chosen at the international airport of Surabaya, Indonesia. In total, there were 21 finalized airport service attributes and grouped into 5 SERVQUAL dimensions used in describing the entire experience in the international airport as shown in Table 3. They were ranged from tangible to intangible attributes such as reliability, responsiveness, empathy, and assurance dimensions.

A pilot test has been conducted, by evaluating and criticizing the wordings and length of the survey. The subjects chosen were those experiencing international airport services from October 2016 to September 2017, which was in the ranging period of 12 months. At least, the subjects have experienced the airport service once either for a domestic or international flight at the period. Considering the study by Hartono and Tan (2011), this study used a face-to-face questionnaire and in-depth interview involving 100 targeted subjects. Convenience sampling was applied. It is also known as opportunity sampling or accidental sampling. It is a non-probability sampling method involving the sample that is close to hand. This study targeted to passengers in an international airport based on the convenience of access. Face validity has been confirmed as the respondents were agreeing to answer the questions regarding their experience in the international airport, and the interviewers showed the instrument before the survey began. It shows that the study went through a measurement of what it was supposed to measure. It took about $20 \mathrm{~min}$ to complete the survey. Due to convenience purposes, if the respondent refuses to do the survey, then the interview will be canceled. This study has only focused on domestic respondents (i.e., Indonesians), hence a culture-based issue was omitted. The respondents consisted of 55\% males and $45 \%$ females. The majority age was at a range of 17-25 years (38\%) with occupation as a private sector employee (39\%). Regarding the frequency of the airport visit, over $65 \%$ of the respondents visited $2-12$ times a year. The details of the respondent profile are shown in Table 4.

Through the survey on the airport services, the Kansei words as the representative of customer emotional needs have been defined. After doing the screening process using an affinity diagram, the collected Kansei words have been finalized. Those Kansei words were as follows, happy, friendly, satisfied, clean, trusted, delighted, nice, and modern. Adopting the previous studies (see Hartono and Tan, 2011; Hartono et al., 2013; Hartono and Raharjo, 2015; Hartono, 2016), Kansei is more dominant than cognition. Thus, by satisfying the emotional needs of

Table 3

Service attributes for international airport lounge and lobby.

\begin{tabular}{|c|c|c|c|}
\hline \multicolumn{2}{|c|}{ Dimension 1: Tangible } & \multicolumn{2}{|c|}{ Dimension 3: Responsiveness } \\
\hline $\mathrm{AL}_{1}$ & $\begin{array}{l}\text { The modernity of airport } \\
\text { building }\end{array}$ & $\mathrm{AL}_{13}$ & $\begin{array}{l}\text { The responsiveness to any } \\
\text { complaints }\end{array}$ \\
\hline $\mathrm{AL}_{2}$ & The hygienic airport & $\mathrm{AL}_{14}$ & $\begin{array}{l}\text { The promptness of problem- } \\
\text { solving }\end{array}$ \\
\hline $\mathrm{AL}_{3}$ & The availability of trollies & $\mathrm{AL}_{15}$ & The courteousness of the staff \\
\hline $\mathrm{AL}_{4}$ & The neatness of airport staff & $\mathrm{AL}_{16}$ & The friendliness of the staff \\
\hline $\mathrm{AL}_{5}$ & The cleanliness of the toilet & $\mathrm{AL}_{17}$ & $\begin{array}{l}\text { The communication skill of the } \\
\text { staff }\end{array}$ \\
\hline $\mathrm{AL}_{6}$ & $\begin{array}{l}\text { The availability of seating } \\
\text { facilities }\end{array}$ & \multicolumn{2}{|c|}{ Dimension 4: Assurance } \\
\hline $\mathrm{AL}_{7}$ & $\begin{array}{l}\text { The availability of check-in } \\
\text { counters }\end{array}$ & $\mathrm{AL}_{18}$ & The secured parking lot \\
\hline \multicolumn{2}{|c|}{ Dimension 2: Reliability } & $\mathrm{AL}_{19}$ & $\begin{array}{l}\text { The availability of security in the } \\
\text { airport lounge and lobby }\end{array}$ \\
\hline $\mathrm{AL}_{8}$ & $\begin{array}{l}\text { The appropriateness of airfare } \\
\text { and service obtained }\end{array}$ & \multicolumn{2}{|c|}{ Dimension 5: Empathy } \\
\hline $\mathrm{AL}_{9}$ & $\begin{array}{l}\text { The accuracy of delay } \\
\text { notification }\end{array}$ & $\mathrm{AL}_{20}$ & $\begin{array}{l}\text { The reactiveness of staff to help } \\
\text { customer }\end{array}$ \\
\hline $\mathrm{AL}_{10}$ & $\begin{array}{l}\text { The accuracy of the delivered } \\
\text { last call }\end{array}$ & $\mathrm{AL}_{21}$ & $\begin{array}{l}\text { The apology was given by the } \\
\text { staff if any mistakes }\end{array}$ \\
\hline $\mathrm{AL}_{11}$ & $\begin{array}{l}\text { The ease of information } \\
\text { obtained }\end{array}$ & & \\
\hline $\mathrm{AL}_{12}$ & $\begin{array}{l}\text { The clarity of information } \\
\text { given by staff }\end{array}$ & & \\
\hline
\end{tabular}

Table 4

Profile of respondents.

\begin{tabular}{|c|c|c|c|c|c|}
\hline Variables & Frequency & $\begin{array}{l}\% \text { of the } \\
\text { total }\end{array}$ & Variables & Frequency & $\begin{array}{l}\% \text { of the } \\
\text { total }\end{array}$ \\
\hline Gender & & & Occupation & & \\
\hline Male & 55 & 55 & Student & 34 & 34 \\
\hline \multirow[t]{4}{*}{ Female } & 45 & 45 & Entrepreneur & 15 & 15 \\
\hline & & & $\begin{array}{l}\text { Public sector } \\
\text { employee }\end{array}$ & 39 & 39 \\
\hline & & & $\begin{array}{l}\text { Government } \\
\text { employee }\end{array}$ & 2 & 2 \\
\hline & & & Housewife & 10 & 10 \\
\hline \multicolumn{6}{|l|}{ Age } \\
\hline $17-25$ & 38 & 38 & $\begin{array}{l}\text { Frequency of } \\
\text { airport visit }\end{array}$ & & \\
\hline $26-35$ & 26 & 26 & Once a year & 25 & 25 \\
\hline $36-45$ & 18 & 18 & $2-12$ times a year & 65 & 65 \\
\hline$>45$ & 18 & 18 & $>12$ times a year & 10 & 10 \\
\hline
\end{tabular}

passengers and users of international airport services, it will bring competitive advantages to the airport authority and loyalty to the entire customers.

Content validity was statistically measured using Pearson's productmoment. It is to measure the correlation between the score of each time and the total score. For service attribute and Kansei constructs, the range of $r$ value for valid items was $0.566-0.765$ and $0.514-0.787$ consecutively, as they are greater than the table's $r$ value for 98 samples (n) was 0.197. In this study, a reliability test was conducted using Cronbach's alpha. It is to test the internal consistency among items statistically, applied in a certain population at a certain time and purpose. At both service attributes and Kansei constructs, it was showed that all items were reliable with Cronbach's alpha values of 0.829 and 0.876 subsequently which greater than the cut-off value of 0.6 . Thus, all measurement items were deemed valid and reliable.

Referring to the Kansei response as a function of perceived service quality especially to those with Kano's attractive [A] and onedimensional [O] category (see Hartono and Tan, 2011; Hartono, 2016), the finalized airport services with Kano's A and O followed by the negative customer satisfaction score are deemed to be priority. The satisfaction score and Kano's category to all service attributes are provided in Table 5. The 5-point Likert scale was used to rate the perception, expectation and importance rating. The Kano's categories were rated to be 4 points [A], 2 points [O] and 1 point [M] (Tan and Pawitra, 2001). The negative customer satisfaction score (here called as satisfaction score) describes the dissatisfaction since the customer expectation is below the customer perception.

According to satisfaction score, it shows that some critical airport service attributes were found, i.e., "the promptness of problem-solving [AL14]", "the accuracy of delay notification [AL9]", and "the responsiveness to any complaints [AL13]". The question is raised. Does it mean we need to focus on these service attributes for improvement? It is unnecessarily true. We need to check the influence of perceived service attributes on Kansei and what Kano category they belong to. The more Kansei they interact with and they belong to Kano's A or O categories, then the more critical and sensitive they are.

Using the formula of Kansei as a function of perceived service quality of Kano's A and O, the selected airport service attributes have been significantly linked to the refined Kansei words through multiple linear regression analysis (as it is shown in Table 6). According to Hartono and Tan (2011), this step is done to identify which Kansei words are critical as the entire representative of customer emotional satisfaction.

The linear model in Table 6 was performed using the multiple linear regression model and analysis. Kansei's response was set to be a dependent variable, whereas airport service attribute perception was set to be an independent variable. Kansei's response is defined as the function of a set of service attribute perceptions (Hartono and Tan, 2011). Data analyzed were Kansei's response score as the dependent 
Table 5

Airport service attributes with negative satisfaction score and Kano categories.

\begin{tabular}{llllll}
\hline Item & Importance & Perception & Expectation & Satisfaction & \\
& & & & & $\begin{array}{l}\text { Kano } \\
\text { category }\end{array}$ \\
\hline $\mathrm{AL}_{1}$ & 4.20 & 3.47 & 4.39 & -3.86 & Must-Be (M) \\
$\mathrm{AL}_{2}$ & 4.44 & 3.39 & 4.48 & -4.84 & Attractive (A) \\
$\mathrm{AL}_{3}$ & 4.10 & 3.17 & 4.09 & -3.77 & Must-Be (M) \\
$\mathrm{AL}_{4}$ & 4.04 & 3.33 & 4.10 & -3.11 & Must-Be (M) \\
$\mathrm{AL}_{5}$ & 4.49 & 3.27 & 4.47 & -5.39 & Attractive (A) \\
$\mathrm{AL}_{6}$ & 4.25 & 2.95 & 4.33 & -5.87 & Must-Be (M) \\
$\mathrm{AL}_{7}$ & 4.04 & 3.15 & 4.18 & -4.16 & Must-Be (M) \\
$\mathrm{AL}_{8}$ & 4.25 & 3.00 & 4.22 & -5.19 & Indifferent (I) \\
$\mathrm{AL}_{9}$ & 4.59 & 3.10 & 4.45 & -6.20 & Attractive (A) \\
$\mathrm{AL}_{10}$ & 4.52 & 3.27 & 4.50 & -5.56 & Attractive (A) \\
$\mathrm{AL}_{11}$ & 4.41 & 3.21 & 4.40 & -5.25 & Attractive (A) \\
$\mathrm{AL}_{12}$ & 4.50 & 3.23 & 4.44 & -5.45 & Attractive (A) \\
$\mathrm{AL}_{13}$ & 4.35 & 3.02 & 4.41 & -6.05 & Must-Be (M) \\
$\mathrm{AL}_{14}$ & 4.42 & 2.97 & 4.39 & -6.28 & Must-Be (M) \\
$\mathrm{AL}_{15}$ & 4.37 & 3.36 & 4.30 & -4.11 & Indifferent (I) \\
$\mathrm{AL}_{16}$ & 4.39 & 3.27 & 4.24 & -4.26 & Indifferent (I) \\
$\mathrm{AL}_{17}$ & 4.39 & 3.32 & 4.34 & -4.48 & Must-Be (M) \\
$\mathrm{AL}_{18}$ & 4.52 & 3.44 & 4.53 & -4.93 & Attractive (A) \\
$\mathrm{AL}_{19}$ & 4.59 & 3.43 & 4.53 & -5.05 & Attractive (A) \\
$\mathrm{AL}_{20}$ & 4.21 & 3.11 & 4.19 & -4.55 & Must-Be (M) \\
$\mathrm{AL}_{21}$ & 4.23 & 3.27 & 4.25 & -4.15 & Must-Be (M) \\
\hline $\mathrm{a}_{2}$ & & & & &
\end{tabular}

${ }^{\text {a }}$ Satisfaction Score $=$ [Perception - Expectation $] \mathrm{x}$ Importance Rating.

Table 6

Kansei-based linear model for airport services.

\begin{tabular}{llll}
\hline No & Kansei & $p$ value & Significant model $^{\mathrm{a}}$ \\
\hline 1 & Happy $\left[\mathrm{K}_{1}\right]$ & 0.001 & $\mathrm{~K}_{1}=2.952+0.341 \mathrm{AL}_{19}$ \\
2 & Friendly $\left[\mathrm{K}_{2}\right]$ & $\mathrm{N} / \mathrm{A}$ & \\
3 & Satisfied $\left[\mathrm{K}_{3}\right]$ & 0.001 & $\mathrm{~K}_{3}=3.164+0.212 \mathrm{AL}_{9}$ \\
4 & Clean $\left[\mathrm{K}_{4}\right]$ & 0.031 & $\mathrm{~K}_{4}=3.230+0.229 \mathrm{AL}_{9}$ \\
5 & Trusted $\left[\mathrm{K}_{5}\right]$ & 0.001 & $\mathrm{~K}_{5}=2.583+0.323 \mathrm{AL}_{19}$ \\
6 & Delighted $\left[\mathrm{K}_{6}\right]$ & 0.000 & $\mathrm{~K}_{6}=1.996+0.412 \mathrm{AL}_{19}$ \\
7 & Nice $\left[\mathrm{K}_{7}\right]$ & 0.003 & $\mathrm{~K}_{7}=2.383+0.352 \mathrm{AL}_{19}$ \\
8 & Modern $\left[\mathrm{K}_{8}\right]$ & 0.001 & $\mathrm{~K}_{8}=2.914+0.264 \mathrm{AL}_{19}$ \\
\hline
\end{tabular}

a Significant with $\alpha \leq 5 \%$; the name of service attributes is provided in Table 3 .

variable $(\mathrm{Y})$ and service attribute perception score as the independent variable (X). According to the modified KE-based application model (see Fig. 4), the Kansei model is set to be a function of the perceived service quality of Kano's A and O (see Table 5). These Kano's A- and O-categorized service attributes are deemed to bring a source of differentiation, drive customer loyalty, and obtain total customer satisfaction (Yang, 2011). They are the main driver for customer delight and Kansei. Through multiple linear regression model and analysis, it was found that only service attribute $\mathrm{AL}_{9}$ and $\mathrm{AL}_{19}$ were significant to certain Kansei words, as provided in Table 6.

The linear models were then modified; to find out which airport service attribute(s) are sensitive. According to Hartono and Tan (2011) and Schutte et al. (2004), a reversed linear model is formed to identify which service attribute(s) are associated with significant Kansei. The significant service attributes included in Table 6 were taken from those associated with significant Kansei (see Table 6) and categorized as Kano's Attractive (A) and One-dimensional (O) (see Table 5). The modification of the model also includes the calculation of importance weight considering the absolute satisfaction score, the Kano category weight, and Kansei's mean score. The "importance weight" is defined by the multiplication of |satisfaction score|, Kano score, an average of Kansei's response mean score, and the number of Kansei impacted (see Hartono et al., 2017). It is used to filter which airport service attribute is prioritized for improvement. Service attributes with lower negative satisfaction scores, higher Kano category (A is the highest), and more Kansei impact will be given higher importance weight. The service attribute with the highest importance weight is deemed to be the most critical one. In other words, the higher the importance of weight, the more important the service attribute is. The detail of importance weight is shown in Table 7.

The confirmatory mechanism of the KE linear model was conducted. It is to check "the true meaning" of the Kansei model. It involved 1 representative of airport management staff and 2 passengers at the interview session. The result of the confirmatory mechanism of KE linear model is provided in Table 8:

Based on the results shown in Table 8, all linear models are deemed valid except for the linear model of Kansei "clean" and service attribute $\mathrm{AL}_{9}$ (The accuracy of delay notification). It was found that the service attribute $\mathrm{AL}_{19}$ (the availability of security in the airport lounge and lobby) was the most critical to the passengers in the international airport. It implies that the airport managers do not need to improve the entire service attributes having a negative customer satisfaction score, however, it would be more efficient to focus only on some key service attributes impacted more on Kansei.

This service attribute "the availability of security in the airport lounge and lobby" was then improved through TRIZ 40 principles (Chai et al., 2005) and contradiction matrix (Shih et al., 2013). The improving feature was "object-affected harmful factors", whereas the worsening features were "power" and "speed". Apart from the TRIZ contradiction analysis, a service designer should consider the sustainability principles for airport services (Berry et al., 2008). Since this study deals with human Kansei satisfaction, thus, the human factor and ergonomics-based sustainability (HF\&E sustainability) are proposed. According to Brown and Legg (2012), HF\&E sustainability can bridge the connection between needs and triple bottom lines' requirements incorporating human characteristics into system design. It seems that the social dimension is quite related to the human factor and ergonomics-based sustainability. It comprises 10 variables such as public awareness and education, stakeholder relationships, employee practices, and procedures, and so forth as shown in Table 9.

Considering the integrated approach of TRIZ and HF\&E sustainability for airport services, taking into account the contradictive items of "object-affected harmful factor" and "power", there are four improvement strategies proposed (Chai et al., 2005), i.e., (i) periodic action, (ii) blessing in disguise/convert harm into benefit, (iii) porous materials and (iv) taking out/extraction. Regarding the contradictive items of "object-affected harmful factor" and "speed", there are also four improvements available, i.e., (i) skipping/rushing through, (ii) blessing in disguise/convert harm into benefit, (iii) parameter change$\mathrm{s}$ /transformation of properties and (iv) mechanics substitution/replacement of mechanical systems. Concerning those improvement strategies, there are proposed possible solutions followed by the solution evaluation. The ideal solution is expected which delivers desirable benefits to the users and it is the free cost of problem-solving. Besides, the desirable idea of a solution can be further modified and refined considering all possible constraints (Chai et al., 2005).

There was a 2 -stage operational validation process conducted. The first stage is to discuss the feasibility of proposed solutions considering the fulfillment of customer needs (customer-oriented) and the availability of resources (provider-oriented). Essentially, it is to evaluate the formulized improvement strategies involving research and the airport management teams, subjected to QCD-based components (i.e., quality, cost, and delivery), innovative ideas, the possibility of implementation, and maximum benefits to public-employee-passenger well-being. The most prioritized and ideal proposed solutions, for now, were as follow: (i) Airport authority provides a porous security in the lounge to check all passengers before boarding and (ii) Airport authority provides a big screen in front of security check counter, demonstrating how to pass through the metal detector and showing the list of forbidden items. Overall, it is to make the security check more efficiently and effectively. The remaining proposed solution items will be considered as a secondary priority. The results are provided in Table 10.

A subsequent stage, called as the second stage, is to promote operational validation by checking the possibility of implementation of 
Table 7

The importance weight of significant service attribute.

\begin{tabular}{|c|c|c|c|c|c|c|}
\hline \multirow[t]{2}{*}{ Attribute } & \multirow[t]{2}{*}{ |Satisfaction Score| } & \multicolumn{2}{|c|}{ Kano Weight } & \multicolumn{2}{|l|}{ Kansei Word } & \multirow[t]{2}{*}{ Importance Weight $^{\mathrm{a}}$} \\
\hline & & Category & Score & Perception of Mean Score & Kansei Impacted & \\
\hline \multirow[t]{5}{*}{$\mathrm{AL}_{19}$} & \multirow[t]{5}{*}{5.049} & \multirow[t]{5}{*}{ A } & \multirow[t]{5}{*}{4} & 3.81 & Happy & \multirow[t]{5}{*}{$366.56^{\mathrm{b}}$} \\
\hline & & & & 3.67 & Trusted & \\
\hline & & & & 3.33 & Delighted & \\
\hline & & & & 3.53 & Nice & \\
\hline & & & & 3.81 & Modern & \\
\hline \multirow[t]{2}{*}{$\mathrm{AL}_{9}$} & \multirow[t]{2}{*}{6.197} & \multirow[t]{2}{*}{ A } & \multirow[t]{2}{*}{4} & 3.81 & Satisfied & \multirow[t]{2}{*}{192.09} \\
\hline & & & & 3.94 & Clean & \\
\hline $\mathrm{AL}_{10}$ & 5.560 & A & 4 & - & - & 22.24 \\
\hline $\mathrm{AL}_{12}$ & 5.445 & $\mathrm{O}$ & 2 & - & - & 10.88 \\
\hline $\mathrm{AL}_{5}$ & 5.388 & A & 4 & - & - & 21.55 \\
\hline $\mathrm{AL}_{11}$ & 5.248 & A & 4 & - & - & 20.99 \\
\hline $\mathrm{AL}_{18}$ & 4.927 & A & 4 & - & - & 19.71 \\
\hline $\mathrm{AL}_{2}$ & 4.840 & A & 4 & - & - & 19.36 \\
\hline
\end{tabular}

a Importance Weight = |Satisfaction Score $\mid \mathrm{x}$ Kano Score x (Average of Kansei Perception Mean Score x number of Kansei).

b The most critical airport service attribute.

proposed strategies and solutions and its reflection on any feedbacks, i. e., to check whether proposed solution and recommendation are accepted, to confirm whether they can be implemented by the service provider and customer considering time, cost and effort (resources), and once again to confirm whether the customer needs are fulfilled and fit. At this stage, it conducted an in-depth focus group discussion (FGD) with loyal passengers of an international airport on the chosen proposed strategies. According to Morgan (1997), 6 loyal passengers were participating in this discussion. They were those visiting and enjoying the international airport services at least three times within 6 months.

Referring to Table 10, a principle of customer-focused is promoted. Customer-focused practice means we put the needs and requirements of our customers ahead of anything and everything else first with respected constraints. The proposed solution "airport authority provides a big screen in front of the security check counter, to demonstrate how to pass through the metal detector and show the list of forbidden items" was confirmed and approved as the primary concern. Currently, several screens are available showing the flight schedule of arrival and departure. It is quite possible to modify it by adding procedures to pass through the metal detectors and show forbidden items in a specific set of a time slot, provided in both visual and auditory messages. "Securityawareness campaign and demonstration during the peak hours and seasons" can be considered as a primary concern as well. This securityawareness campaign can be held considering available extra slots during the peak hours and seasons. Another primary concern is service attribute "airport authority provides a porous and simplified security check in the lounge before boarding". It is to ensure a multi-layered safety inside the airport lounge so that passengers will feel no worries of insecurity right before they depart. Flying journey experience with joy and happiness is highly expected. Strict rules and regulations are guaranteed.

Apart from primary concern, the secondary one was defined as follows. Service attribute "regular safety audit" was considered secondary since it is deemed more on internal management decisions and indirectly affecting the customers/passengers. "Electronic-based security systems such as face and voice recognition" should be attached and implemented in designated corners of the airport. Concerning cost and direct impact on customers, this e-based system is set to be a secondary concern. All secondary concerns will be accomplished once all primary ones already settled.

Again, safety is deemed to be a must for passengers. After the $9 / 11$ incident, airport security and safety is confirmed to be a compulsory practice for passengers. International airports have been the focus of security practices and concerns for several decades. Security and safety will count about $30 \%$ of the operating costs of an international airport. A simple organization, i.e., international airport service, has shown the applicability of the proposed methodology as discussed above.

\section{Discussion}

Kansei Engineering (KE) is proposed to link the customer's emotional needs (Kansei) and responses to the properties and attributes of a product or service. Hence, products or services should be designed to bring forward the intended user feelings and emotions. The success of a product or service in a certain market segment not only expects knowledge about the performance of competing products or services but also the emotional needs and impressions which a product or service leaves to the users and customers.

As the largest sector of today's economy, service industries need more sustainable practices. Sustainable service, a new term for sustainability-based service, concerns on environmental services which focus on the reduction of environmental damage and impact and the maximization of more efficient resource use. This sustainable service practice will promote more eco-efficient services which are capable of satisfying customer needs more sustainably (Wolfson et al., 2015). In other words, it is called a green service or an environmentally friendly service. Essentially, sustainable services can be implemented through three stages of the service life cycle, namely: design, production-delivery, and use. Sustainable services serve as sources of both customer and employee satisfaction which lead to something beyond profitability. Sustainable service provides the service's core values for both provider and customer which leads to service innovation. Exploring and finding the hidden and latent needs which correspond to certain service attributes is a challenge for service innovation and sustainability (Yang, 2011).

A study on services incorporating sustainability concept is quite limited, especially for those with emotional needs (known as Kansei) concern. This current study which is considering Kansei Engineering (KE) as the backbone of research methodology is in line with the concern of sustainable service. It shows step-by-step methodology in filtering and prioritizing the service attributes which are most sensitive to Kansei. The first step, it is known as SERVQUAL and Kano modeling. Through the Kano model, we can dig and find the performance of each service attribute based on customer perception and filter the most critical service attributes called the delighter or attractive category [A] (Hartono and Tan, 2011). The second step, it is called as synthesis and linear modeling. It shows that this study focuses only on Kano's one-dimensional [O] and attractive [A] categories' service attributes with a negative satisfaction score and is validated through the "true meaning" of Kansei. The third step is to promote sustainability principles by highlighting more social and human-based characteristics and more innovative and breakthrough solutions with less contradiction into proposed solutions and strategies. In environmentally friendly services, there is an exchange of intangible value between supplier/provider and consumer/customer with the expectation of co-creation based, greener 
Table 8

Interview-based Kansei description.

\begin{tabular}{|c|c|c|c|}
\hline Kansei & $\begin{array}{l}\text { Significant service } \\
\text { attributes based on } \\
\text { Kansei linear } \\
\text { model }\end{array}$ & $\begin{array}{l}\text { Description of Kansei } \\
\text { related to service } \\
\text { attributes }\end{array}$ & $\begin{array}{l}\text { Confirmation of } \\
\text { service attribute? } \\
\text { [Yes/No] }\end{array}$ \\
\hline Happy & $\begin{array}{l}\mathrm{AL}_{19} \text { The } \\
\text { availability of } \\
\text { security in the } \\
\text { airport lounge and } \\
\text { lobby }\end{array}$ & $\begin{array}{l}\text { - Happy is related to } \\
\text { waiting and enjoying } \\
\text { the airport lounge and } \\
\text { lobby with no worries of } \\
\text { insecurity } \\
\text { - The passengers feel safe } \\
\text { enough as they stay at } \\
\text { their own home } \\
\text { - Food court and } \\
\text { entertainment area are } \\
\text { provided }\end{array}$ & Yes \\
\hline Satisfied & $\begin{array}{l}\text { AL } 9 \text { The accuracy } \\
\text { of delay } \\
\text { notification }\end{array}$ & $\begin{array}{l}\text { - Once there is a certainty } \\
\text { to wait for any delays } \\
\text { - On-time flight }\end{array}$ & Yes \\
\hline Clean & $\begin{array}{l}\mathrm{AL}_{9} \text { The accuracy } \\
\text { of delay } \\
\text { notification }\end{array}$ & $\begin{array}{l}\text { - Odorless environment } \\
\text { - Clean toilet, lobby, and } \\
\text { lounge }\end{array}$ & $\mathrm{No}^{\mathrm{a}}$ \\
\hline Trusted & $\begin{array}{l}\mathrm{AL}_{19} \text { The } \\
\text { availability of } \\
\text { security in the } \\
\text { airport lounge and } \\
\text { lobby }\end{array}$ & $\begin{array}{l}\text { - To trust the airport } \\
\text { environment is safe and } \\
\text { secure } \\
\text { - Trust is supported by a } \\
\text { security system }\end{array}$ & Yes \\
\hline Delighted & $\begin{array}{l}\mathrm{AL}_{19} \text { The } \\
\text { availability of } \\
\text { security in the } \\
\text { airport lounge and } \\
\text { lobby }\end{array}$ & $\begin{array}{l}\text { - No worries for } \\
\text { passengers when they } \\
\text { are in the airport lounge } \\
\text { and lobby } \\
\text { - Delighted since the } \\
\text { airport service is } \\
\text { responsible for the } \\
\text { safety of passenger } \\
\text { which is the most } \\
\text { critical assurance for all } \\
\text { passengers. In addition } \\
\text { to that, an international } \\
\text { airport is full of people } \\
\text { around the world, hence } \\
\text { the strict regulation on } \\
\text { safety is a must }\end{array}$ & Yes \\
\hline Nice & $\begin{array}{l}\mathrm{AL}_{19} \text { The } \\
\text { availability of } \\
\text { security in the } \\
\text { airport lounge and } \\
\text { lobby }\end{array}$ & $\begin{array}{l}\text { - The airport facility } \\
\text { looks nice and complete } \\
\text { when it is equipped with } \\
\text { security facilities } \\
\text { - Spacious and not too } \\
\text { crowded with people }\end{array}$ & Yes \\
\hline Modern & $\begin{array}{l}\mathrm{AL}_{19} \text { The } \\
\text { availability of } \\
\text { security in the } \\
\text { airport lounge and } \\
\text { lobby }\end{array}$ & $\begin{array}{l}\text { - The airport looks } \\
\text { modern and up-to-date } \\
\text { and it is a must for the } \\
\text { international airport } \\
\text { once it is equipped with } \\
\text { a CCTV camera and } \\
\text { other security facilities } \\
\text { - Compared with other } \\
\text { international airports in } \\
\text { other big cities, the } \\
\text { installed security } \\
\text { facility and procedure } \\
\text { are deemed to make the } \\
\text { airport up to date }\end{array}$ & Yes \\
\hline
\end{tabular}

\footnotetext{
a The linear model of Kansei "clean" and AL9 is omitted.
}

supply chain and greener value (Wolfson et al., 2015). Nevertheless, the main and basic driver for environmentally friendly services is that economic profit.

According to Sakao and Lindahl (2009) and Beuren et al. (2013), another term for sustainable service is known as product-service systems (PSS). It is an approach to obtain maximum added value by proposing servicizing at the service-added product, i.e., the intensification of the service component of PSS by dictating the service provider in serving functionality rather than a physical product, while the customer will
Table 9

Sustainability dimensions in airport services (Brown and Legg, 2012).

\begin{tabular}{|c|c|c|}
\hline Environmental & Social & Economic \\
\hline Water quality & $\begin{array}{l}\text { Public awareness and } \\
\text { education }\end{array}$ & Local hiring \\
\hline Climate change & Stakeholder relationships & Local purchasing \\
\hline Air quality & $\begin{array}{l}\text { Employee practices and } \\
\text { procedures }\end{array}$ & Contribution to community \\
\hline Land use & Sustainable transportation & Quantifying sustainability \\
\hline Biodiversity & Alleviating road congestion & $\begin{array}{l}\text { Contribution to research and } \\
\text { development }\end{array}$ \\
\hline Materials & Accessibility & $\begin{array}{l}\text { Incentives for sustainable } \\
\text { behavior }\end{array}$ \\
\hline Waste & $\begin{array}{l}\text { Local identity culture and } \\
\text { heritage }\end{array}$ & \\
\hline $\begin{array}{l}\text { Noise and } \\
\text { aesthetics }\end{array}$ & $\begin{array}{l}\text { Indoor environmental } \\
\text { quality }\end{array}$ & \\
\hline Energy & Employee well-being & \\
\hline Green buildings & Passenger well-being & \\
\hline
\end{tabular}

involve in the co-creation of the value. Inherently, PSS addresses three main components in terms of sustainability, i.e., the added value of product and service combination, co-creation process value, and the inspired sustainability-based solution. The core idea is to minimize resource utilization while increasing the responsibility of both provider and customer and growing the business profit.

Within a sustainability frame, this current study uses convergent thinking, which is oriented towards finding and deriving the single feasible best solution to a clearly defined problem (Cropley, 2006). This approach emphasizes the logic, speed, and accuracy and focuses on reapplying well-known set techniques and accumulating information. It is considered effective and also efficient as we apply conventional and logical search and decision-making strategies given ready-made information (Cropley, 2006). In other words, all inputs and ideas are fit to get the right answer within a constraint set.

Figs. 2, 3 and 4 show the milestones of Kansei Engineering (KE) methodology applied in services. Fig. 2 shows the generic KE methodology for product design and development. It starts with the exploration of Kansei words (as the representative of emotional needs) and product properties and ends with the Kansei mathematical model. This model shows the relationship between Kansei and its related product attributes. Fig. 3 shows the modified KE methodology applied in service design and development. It is how KE methodology not only dealing with tangible products but also intangible products known as services. A similar KE methodology has been generated with additional enhancement incorporating cultural differences and TRIZ methodology. Practically, it modifies the previous model by promoting less-contradiction solution analysis. In Fig. 4, it is shown a modified KE methodology incorporating sustainability approach for service design and development. Apart from TRIZ and Kano categorization, in promoting more efficient and effective methodology, this applicative framework proposes a KE-based confirmatory approach known as Kansei "true-meaning". It is a mechanism to qualitatively validating the appropriate Kansei words influenced by certain perceived service attributes. An empirical study on international airport services has shown the applicability of the proposed model.

A question is raised, how to fulfill the real Kansei? How to ensure that all proposed solutions will satisfy the Kansei once they are implemented? For instance, "happy" Kansei is related to waiting and enjoying the airport lounge with no worries of insecurity. According to the focus group discussion (FGD) with loyal passengers visiting the international airport at least three times within six months, it was found that they agreed with the proposed solutions. The proposed solutions such as the provision of a big screen showing the access and list of forbidden items, security-awareness campaign, and simplified security check-in were deemed to be primary-concerned practices. Apart from that, the secondary-concerned practice such as "electronic-based security 
Table 10

TRIZ and HF\&E sustainability-based social dimension for generating alternative solutions.

\begin{tabular}{|c|c|}
\hline \multicolumn{2}{|c|}{$\begin{array}{l}\text { 'Object-affected harmful factor’ vs } \\
\text { 'power' }\end{array}$} \\
\hline $\begin{array}{l}\text { Proposed solution } \\
\text { items }\end{array}$ & Remarks \\
\hline $\begin{array}{l}{ }^{\text {a }} \text { Airport } \\
\text { authority should } \\
\text { provide security- } \\
\text { awareness } \\
\text { campaign and } \\
\text { demonstration } \\
\text { during the peak } \\
\text { hours and } \\
\text { season. }\end{array}$ & $\begin{array}{l}\text { TRIZ-based: This } \\
\text { item is closely } \\
\text { related to a } \\
\text { principle of } \\
\text { "instead of } \\
\text { continuous action, } \\
\text { use periodic or } \\
\text { pulsating action". } \\
\text { HF\&E } \\
\text { sustainability- } \\
\text { based: It is also to } \\
\text { support the item } \\
\text { of "public } \\
\text { awareness" of the } \\
\text { social dimension } \\
\text { in the sustainable } \\
\text { airport service. }\end{array}$ \\
\hline
\end{tabular}

Regular safety audit in the airport lobby and lounge.

$\begin{array}{ll}\text { airport } & \text { TRIZ-based: This } \\ \text { authority } & \text { item is in line } \\ \text { provides porous } & \text { with a principle } \\ \text { security in the } & \text { of "make an object } \\ \text { lounge to check } & \text { or system porous } \\ \text { all passengers } & \text { or add porous } \\ \text { before boarding. } & \begin{array}{l}\text { elements". } \\ \text { HF\&E } \\ \text { sustainability- } \\ \text { based: It suits the } \\ \text { item of "public } \\ \text { awareness and } \\ \text { education; } \\ \text { stakeholder } \\ \text { relationship; } \\ \text { employment } \\ \text { practices and } \\ \text { procedures". }\end{array} \\ & \begin{array}{l}\text { TRIZ-based: This } \\ \text { item is in line } \\ \text { with a principle }\end{array} \\ & \\ \text { E-security system } & \\ \text { to declare what } & \\ & \end{array}$

'Object-affected harmful factor' vs 'speed'

\begin{tabular}{|c|c|c|c|}
\hline & & items & \\
\hline $\begin{array}{l}\text { Proposed solution } \\
\text { items }\end{array}$ & Remarks & $\begin{array}{l}\text { items carried } \\
\text { during the flight. }\end{array}$ & $\begin{array}{l}\text { of "separate an } \\
\text { interfering part or }\end{array}$ \\
\hline $\begin{array}{l}\text { airport } \\
\text { authority } \\
\text { provides a big } \\
\text { screen in front of } \\
\text { the security } \\
\text { check counter, } \\
\text { demonstrating } \\
\text { how to pass } \\
\text { through the } \\
\text { metal detector } \\
\text { and showing the } \\
\text { list of forbidden } \\
\text { items. }\end{array}$ & $\begin{array}{l}\text { TRIZ-based: This } \\
\text { item is closely } \\
\text { related to a } \\
\text { principle of } \\
\text { "conduct a process } \\
\text { or certain stages } \\
\text { (e.g., destructible, } \\
\text { harmful, or } \\
\text { hazardous } \\
\text { operations) at high } \\
\text { speed". } \\
\text { HF\&E } \\
\text { sustainability- } \\
\text { based: It is also to } \\
\text { support the item } \\
\text { of "public } \\
\text { awareness and } \\
\text { education; } \\
\text { employment } \\
\text { practices and }\end{array}$ & & $\begin{array}{l}\text { property from an } \\
\text { object or system, } \\
\text { or single out the } \\
\text { only necessary } \\
\text { part (or property) } \\
\text { of an object or } \\
\text { system". } \\
\text { HF\&E } \\
\text { sustainability- } \\
\text { based: It } \\
\text { complies with the } \\
\text { item of "public } \\
\text { awareness and } \\
\text { education; } \\
\text { stakeholder } \\
\text { relationships; } \\
\text { employment } \\
\text { practices and } \\
\text { procedures; } \\
\text { accessibility" }\end{array}$ \\
\hline
\end{tabular}

Table 10 (continued)

\begin{tabular}{|c|c|c|c|}
\hline \multicolumn{2}{|c|}{$\begin{array}{l}\text { 'Object-affected harmful factor' vs } \\
\text { 'power' }\end{array}$} & \multicolumn{2}{|c|}{$\begin{array}{l}\text { 'Object-affected harmful factor' vs } \\
\text { 'speed' }\end{array}$} \\
\hline $\begin{array}{l}\text { Proposed solution } \\
\text { items }\end{array}$ & Remarks & $\begin{array}{l}\text { Proposed solution } \\
\text { items }\end{array}$ & Remarks \\
\hline $\begin{array}{l}\text { items carried } \\
\text { during the flight. }\end{array}$ & $\begin{array}{l}\text { of "separate an } \\
\text { interfering part or } \\
\text { property from an } \\
\text { object or system, } \\
\text { or single out the } \\
\text { only necessary } \\
\text { part (or property) } \\
\text { of an object or } \\
\text { system". } \\
\text { HF\&E } \\
\text { sustainability- } \\
\text { based: It } \\
\text { complies with the } \\
\text { item of "public } \\
\text { awareness and } \\
\text { education; } \\
\text { stakeholder } \\
\text { relationships; } \\
\text { employment } \\
\text { practices and } \\
\text { procedures; } \\
\text { accessibility" }\end{array}$ & $\begin{array}{l}\text { system using a } \\
\text { camera-based face } \\
\text { and voice } \\
\text { recognition. }\end{array}$ & $\begin{array}{l}\text { principle of } \\
\text { "replace a } \\
\text { mechanical means } \\
\text { with a sensory } \\
\text { (optical, acoustic, } \\
\text { taste, or smell)". } \\
\text { HF\&E } \\
\text { sustainability- } \\
\text { based: It is also to } \\
\text { support the item } \\
\text { of "public } \\
\text { awareness and } \\
\text { education; } \\
\text { stakeholder } \\
\text { relationships; } \\
\text { employment } \\
\text { practices and } \\
\text { procedures; indoor } \\
\text { environmental } \\
\text { quality" of the } \\
\text { social dimension } \\
\text { in the sustainable } \\
\text { airport service. }\end{array}$ \\
\hline
\end{tabular}

${ }^{\text {a }}$ Most prioritized and possible executed proposed solutions (the primary concern).

congestion" of the

social dimension

in the sustainable airport service.

TRIZ-based: This

Regular safety audit in the airport item is closely lobby and lounge.

related to a principle of "use harmful factors (particularly, harmful effects of the environment or surroundings) to achieve a positive effect".

HF\&E

sustainability-

based: It is also to support the item of "employee practices and procedures" of the social dimension in the sustainable airport service.

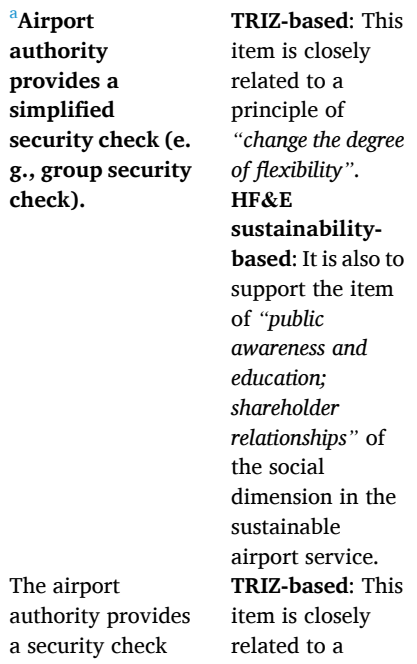

systems, for instance, face and voice recognition" has been formulated. It will be launched once the primary ones have been settled. Regular updates and evaluation of the implementation of the proposed solution will be conducted. Any passenger and customer feedback will be collected. Regarding the face and voice recognition for a security system, firstly, it is better to socialize and educate the passengers of how this security system works before it is implemented. It may be done by visualizing and marketing this idea of a security system in the designated spots of an international airport.

Theoretical and practical contributions are as follow. Theoretically, this study provides a formal and comprehensive methodology in promoting sustainability in service design and development. More specifically, it focuses on the most critical service attributes to be continuously improved considering emotional needs (Kansei) as the customer hidden needs (customer-oriented) combined with more efficient use of resources (provider-oriented). It combines several service quality tools, human factors engineering, and sustainable service design and development. Practically, this study serves guidance for international airport management and staff to prioritize the service attributes to be continuously improved and enhanced subjected to customer Kansei, innovative yet less-contradictory strategies, available resources, and sustainability concern. This practical guidance is served as a comprehensive applicative model/framework. Through two-stage operational validation, the expected outcomes were deemed relevant to practice. Related to the practical execution of proposed solutions, a prioritization strategy concerning available constraints is promoted.

\section{Conclusion and further research}

This study on the modified Kansei Engineering-based application for sustainable service design has been proposed incorporating TRIZ and human factor and ergonomics concerns. The concept of 3Ps (people, planet, and profit) has been embedded into the main methodology of KE especially the social dimension which is closely related to human factors. This study took an empirical study of international airport services to verify the applicability of the proposed method. The finding shows the practical guideline for the airport management team to continuously carry out service improvements considering resource constraint, 
innovative ideas, and emotional satisfaction (Kansei). Also, the proposed improvement is expected to be less contradictory and less experiencedbased knowledge dependency.

This study is limited due to the small sample size and contextualbased case study. Due to the more complex system in the future, culture-based and human cyber-physical system approach can be potentially considered for generating and executing the possible innovative ideas. For future studies, hotel service will be considered as one of the service settings. At a hotel, people can do many things as they stay at their own home. Hotels do not sell room nights, they sell time. It would be nice if we are staying in a hotel as if it is our own home. We expect a whole life-cycle package, i.e., sleeping, showering, eating, and experiencing warm and friendly service from hotel staff.

\section{Declaration of competing interest}

The authors declare that they have no known competing financial interests or personal relationships that could have appeared to influence the work reported in this paper.

\section{CRediT authorship contribution statement}

Markus Hartono: Conceptualization, Methodology, Formal analysis, Validation, Writing - original draft, Writing - review \& editing, Supervision, Visualization.

\section{Acknowledgment}

This study was fully supported by the research grant of The Ministry of Research, Technology, and the Higher Education Republic of Indonesia and the Department of Industrial Engineering, University of Surabaya, Surabaya, Indonesia, with a contract number of $120 / \mathrm{SP} 2 \mathrm{H} /$ LT/DRPM/2018. The authors would like to thank the anonymous reviewers of this paper for their efforts in providing constructive feedback.

\section{Appendix A. Supplementary data}

Supplementary data to this article can be found online at https://doi.org/10.1016/j.ergon.2020.102985.

\section{APPENDIX}

Sample questionnaire for airport services: service quality, Kansei, and Kano.

The purpose of this survey is to collect information on your experience in airport services. You will take less than 20 min to complete. All information given will be kept strictly confidential.

\section{Section A (omitted). It is general information on respondent profile}

Section B. Airport Service Quality (partial sample)

Based on your experience as a passenger of airport services, please think about the importance of services provided (Importance), show the extent to which you think such an airport would possess the services (Expectation), and show the extent to which you believe the airport has the services (Perception). If you strongly disagree, tick ' 1 '; if you strongly agree, tick ' 5 '.

\begin{tabular}{|c|c|c|c|c|c|c|c|c|c|c|c|c|c|c|c|}
\hline \multirow{2}{*}{$\begin{array}{l}\text { Service Attributes } \\
\mathrm{AL}_{1} \text {. The modernity of airport building }\end{array}$} & \multicolumn{5}{|c|}{ Importance } & \multicolumn{5}{|c|}{ Expectation } & \multicolumn{5}{|c|}{ Perception } \\
\hline & 1 & 2 & 3 & 4 & 5 & 1 & 2 & 3 & 4 & 5 & 1 & 2 & 3 & 4 & 5 \\
\hline $\mathrm{AL}_{2}$. The hygienic airport & 1 & 2 & 3 & 4 & 5 & 1 & 2 & 3 & 4 & 5 & 1 & 2 & 3 & 4 & 5 \\
\hline $\mathrm{AL}_{3}$. The availability of trollies & 1 & 2 & 3 & 4 & 5 & 1 & 2 & 3 & 4 & 5 & 1 & 2 & 3 & 4 & 5 \\
\hline AL4. The neatness of airport staff & 1 & 2 & 3 & 4 & 5 & 1 & 2 & 3 & 4 & 5 & 1 & 2 & 3 & 4 & 5 \\
\hline $\mathrm{AL}_{5}$. The cleanliness of the toilet & 1 & 2 & 3 & 4 & 5 & 1 & 2 & 3 & 4 & 5 & 1 & 2 & 3 & 4 & 5 \\
\hline $\mathrm{AL}_{6}$. The availability of seating facilities & 1 & 2 & 3 & 4 & 5 & 1 & 2 & 3 & 4 & 5 & 1 & 2 & 3 & 4 & 5 \\
\hline AL7. The availability of check-in counters & 1 & 2 & 3 & 4 & 5 & 1 & 2 & 3 & 4 & 5 & 1 & 2 & 3 & 4 & 5 \\
\hline $\mathrm{AL}_{8}$. The appropriateness of airfare and service obtained & 1 & 2 & 3 & 4 & 5 & 1 & 2 & 3 & 4 & 5 & 1 & 2 & 3 & 4 & 5 \\
\hline ALg. The accuracy of delay notification & 1 & 2 & 3 & 4 & 5 & 1 & 2 & 3 & 4 & 5 & 1 & 2 & 3 & 4 & 5 \\
\hline $\mathrm{AL}_{10}$. The accuracy of the delivered last call & 1 & 2 & 3 & 4 & 5 & 1 & 2 & 3 & 4 & 5 & 1 & 2 & 3 & 4 & 5 \\
\hline $\mathrm{AL}_{11}$. The ease of information obtained & 1 & 2 & 3 & 4 & 5 & 1 & 2 & 3 & 4 & 5 & 1 & 2 & 3 & 4 & 5 \\
\hline $\mathrm{AL}_{12}$. The clarity of information given by staff & 1 & 2 & 3 & 4 & 5 & 1 & 2 & 3 & 4 & 5 & 1 & 2 & 3 & 4 & 5 \\
\hline $\mathrm{AL}_{13}$. The responsiveness to any complaints & 1 & 2 & 3 & 4 & 5 & 1 & 2 & 3 & 4 & 5 & 1 & 2 & 3 & 4 & 5 \\
\hline $\mathrm{AL}_{14}$. The promptness of problem-solving & 1 & 2 & 3 & 4 & 5 & 1 & 2 & 3 & 4 & 5 & 1 & 2 & 3 & 4 & 5 \\
\hline $\mathrm{AL}_{15}$. The courteousness of the staff & 1 & 2 & 3 & 4 & 5 & 1 & 2 & 3 & 4 & 5 & 1 & 2 & 3 & 4 & 5 \\
\hline $\mathrm{AL}_{16}$. The friendliness of the staff & 1 & 2 & 3 & 4 & 5 & 1 & 2 & 3 & 4 & 5 & 1 & 2 & 3 & 4 & 5 \\
\hline $\mathrm{AL}_{17}$. The communication skill of the staff & 1 & 2 & 3 & 4 & 5 & 1 & 2 & 3 & 4 & 5 & 1 & 2 & 3 & 4 & 5 \\
\hline $\mathrm{AL}_{18}$. The secured parking lot & 1 & 2 & 3 & 4 & 5 & 1 & 2 & 3 & 4 & 5 & 1 & 2 & 3 & 4 & 5 \\
\hline $\mathrm{AL}_{19}$. The availability of security in the airport lounge and lobby & 1 & 2 & 3 & 4 & 5 & 1 & 2 & 3 & 4 & 5 & 1 & 2 & 3 & 4 & 5 \\
\hline $\mathrm{AL}_{20 .}$. The proactiveness of staff to help customer & 1 & 2 & 3 & 4 & 5 & 1 & 2 & 3 & 4 & 5 & 1 & 2 & 3 & 4 & 5 \\
\hline AL21. The apology was given by the staff if any mistakes & 1 & 2 & 3 & 4 & 5 & 1 & 2 & 3 & 4 & 5 & 1 & 2 & 3 & 4 & 5 \\
\hline
\end{tabular}

Section C. Kansei (partial sample)

Based on your experience as a passenger of airport services, please rate the fulfillment of your Kansei by ticking the rating on a Likert scale of 1 (absolutely negative Kansei) to 5 (absolutely positive Kansei). 


\begin{tabular}{|c|c|c|c|c|c|c|c|}
\hline \multirow{2}{*}{$\frac{\text { Code }}{\mathrm{K}_{1}}$} & \multirow{2}{*}{$\begin{array}{l}\text { Negative Kansei } \\
\text { Unhappy }\end{array}$} & \multicolumn{5}{|c|}{ Experience Rating } & \multirow{2}{*}{$\begin{array}{l}\text { Positive Kansei } \\
\text { Happy }\end{array}$} \\
\hline & & 1 & 2 & 3 & 4 & 5 & \\
\hline $\mathrm{K}_{2}$ & Unfriendly & 1 & 2 & 3 & 4 & 5 & Friendly \\
\hline $\mathrm{K}_{3}$ & Unsatisfied & 1 & 2 & 3 & 4 & 5 & Satisfied \\
\hline $\mathrm{K}_{4}$ & Dirty & 1 & 2 & 3 & 4 & 5 & Clean \\
\hline $\mathrm{K}_{5}$ & Distrusted & 1 & 2 & 3 & 4 & 5 & Trusted \\
\hline $\mathrm{K}_{6}$ & Bored & 1 & 2 & 3 & 4 & 5 & Delighted \\
\hline $\mathrm{K}_{7}$ & Ugly & 1 & 2 & 3 & 4 & 5 & Nice \\
\hline $\mathrm{K}_{8}$ & Old-fashioned & 1 & 2 & 3 & 4 & 5 & Modern \\
\hline
\end{tabular}

\section{Section D. Kano (partial sample)}

Based on your experience as a passenger of airport services, please encircle one of the following five choices: 1 =I enjoy it that way; 2 =I expect it that way; 3 = I am neutral; 4 = I dislike it but I can live with it that way; 5 = I dislike it and I cannot accept it.

\begin{tabular}{|c|c|c|c|c|c|c|}
\hline \multirow{2}{*}{$\frac{\text { Code }}{\mathrm{AL}_{1}}$} & \multirow{2}{*}{$\begin{array}{l}\text { Functionality/Disfunctionality of Service Attributes } \\
\text { There is modernity of airport building }\end{array}$} & \multicolumn{5}{|c|}{ Choices } \\
\hline & & 1 & 2 & 3 & 4 & 5 \\
\hline & There is not modernity of airport building & 1 & 2 & 3 & 4 & 5 \\
\hline \multirow[t]{2}{*}{$\mathrm{AL}_{2}$} & The airport is hygienic & 1 & 2 & 3 & 4 & 5 \\
\hline & The airport is not hygienic & 1 & 2 & 3 & 4 & 5 \\
\hline \multirow[t]{2}{*}{$\mathrm{AL}_{3}$} & There is availability of trollies & 1 & 2 & 3 & 4 & 5 \\
\hline & There is not availability of trollies & 1 & 2 & 3 & 4 & 5 \\
\hline \multirow[t]{2}{*}{$\mathrm{AL}_{4}$} & There is neatness of airport staff & 1 & 2 & 3 & 4 & 5 \\
\hline & There is not neatness of airport staff & 1 & 2 & 3 & 4 & 5 \\
\hline \multirow[t]{2}{*}{$\mathrm{AL}_{5}$} & The toilet is clean & 1 & 2 & 3 & 4 & 5 \\
\hline & The toilet is not clean & 1 & 2 & 3 & 4 & 5 \\
\hline \multirow[t]{2}{*}{$\mathrm{AL}_{6}$} & There is availability of seating facilities & 1 & 2 & 3 & 4 & 5 \\
\hline & There is not availability of seating facilities & 1 & 2 & 3 & 4 & 5 \\
\hline \multirow[t]{2}{*}{$\mathrm{AL}_{20}$} & There is reactiveness of staff to help customer & 1 & 2 & 3 & 4 & 5 \\
\hline & There is not reactiveness of staff to help customer & 1 & 2 & 3 & 4 & 5 \\
\hline \multirow{2}{*}{$\mathrm{AL}_{21}$} & The apology was given by the staff if any mistakes & 1 & 2 & 3 & 4 & 5 \\
\hline & The apology was not given by the staff if any mistakes & 1 & 2 & 3 & 4 & 5 \\
\hline
\end{tabular}

\section{References}

Altshuller, G.S., 1997. 40 principles: TRIZ keys to Technical Innovation. In: Shulyak, L., Rodman, S. (Eds.), Technical Innovation Center. Worcester, Massachusetts, USA.

Berry, F., Gillhespy, S., Rogers, J., 2008. Airport Sustainability Practice. Arup North America, Ltd, San Fransisco.

Beuren, F.H., Ferreira, M.G.G., Miguel, P.A.C., 2013. Product-service systems: a literature review on integrated products and services. J. Clean. Prod. 47, 222-231.

Brown, C., Legg, S., 2012. Human factors and ergonomics for business sustainability. In: Brown, C., Legg, S. (Eds.), Business and Sustainability: Concepts, Strategies, and Changes Critical Studies on Corporate Responsibility, Governance, and Sustainability. Emerald Group, pp. 59-79.

Carreira, R., Patricio, L., Jorge, R.N., Magee, C.L., 2013. Development of an extended Kansei engineering method to incorporate experience requirements in productservice system design. J. Eng. Des. 24 (10), 738-764.

Chai, K.H., Jun, Z., Tan, K.C., 2005. A TRIZ-based method for new service design. J. Serv. Res. 8 (1), 48-66.

Chen, M.-C., Hsu, C.-L., Chang, K.-C., Chou, M.-C., 2015. Applying Kansei Engineering to design logistics services: a case of home delivery service. Int. J. Ind. Ergon. 48, 46-59.

Chen, P.-C., Alvarado, V., Hsu, S.-C., 2018. Water energy nexus in city and hinterlands: multi-regional physical input-output analysis for Hong Kong and South China. Appl. Energy 225, 986-997.

Cotton, B., 2007. The modern airport, conquering complexity in an era of increasing expectations. In: A Frost \& Sullivan White Paper, Document \#TTWO3007- USEN-00.

Cropley, A., 2006. Praise of convergent thinking. Creativ. Res. J. 18 (3), 391-404.

Dekker, S.W.A., Hancock, P.A., Wilkin, P., 2013. Ergonomics and sustainability: towards an embrace of complexity and emergence. Ergonomics 56 (3), 357-364.

Dixon, M., Freeman, K., Toman, N., 2010. Stop trying to delight your customers. Harvard Business Review 88 (7/8), 116-122.

Grandjean, E., 1980. Fitting the Task to the Man. Taylor \& Francis, Ltd, London.

Hartono, M., 2012. Incorporating service quality tools into Kansei Engineering in services: a case study of Indonesian tourists. Procedia Economics and Finance 4, 201-212.

Hartono, M., 2016. The extended integrated model of Kansei engineering, Kano, and TRIZ incorporating cultural differences into services. Int J Technol 1, 97-104.

Hartono, M., Raharjo, H., 2015. Exploring the mediating role of affective and cognitive satisfaction on the effect of service quality on loyalty. Total Qual. Manag. Bus. Excel. 26 (9-10), 971-985.

Hartono, M., Tan, K.C., 2011. How the Kano model contributes to Kansei engineering in services. Ergonomics 54 (11), 987-1004.
Hartono, M., Tan, K.C., Peacock, J.B., 2013. Applying Kansei engineering, the Kano model and QFD to services. Int. J. Serv. Econ. Manag. 5 (3), 256-274.

Hartono, M., Santoso, A., Prayogo, D.N., 2017. How Kansei Engineering, Kano and QFD can improve logistics services. Int J Technol 8 (6), 1070-1081.

Hartono, M., Santoso, A., Prayogo, D.N., 2018. Ergonomics-based Kansei Engineering and Kano model for public services excellence. In: Proceeding of the International Conference on Industrial Engineering and Operations Management. March 6- 8, 2018, Bandung, Indonesia.

Kano, K.H., Hinterhuber, H.H., Bailon, F., Sauerwein, E., 1984. How to delight your customers. J. Prod. Brand Manag. 5 (2), 6-17.

Khalid, H.M., Helander, M.G., 2006. Customer emotional needs in product design. Concurr. Eng.: Res and Appl 14 (3), 197-206.

Ladhari, R., 2009. Service quality, emotional satisfaction, and behavioral intentions: a study in the hotel industry. Manag. Serv. Qual. 19 (3), 308-331.

Lin, I.Y., 2004. Evaluating a servicescape: the effect of cognition and emotion. Int. J. Hospit. Manag. 23, 163-178.

Llinares, C., Page, A.F., 2011. Kano's model in Kansei Engineering to evaluate subjective real estate consumer preferences. Int. J. Ind. Ergon. 41, 233-246.

Manuaba, A., 2007. A total approach in ergonomics is a must to attain humane, competitive and sustainable work systems and products. J. Hum. Ergol. 36, 23-30.

Morgan, D.L., 1997. Focus Groups as Qualitative Research. Sage Publications, Thousand Oaks.

Nagamachi, M., 1995. Kansei engineering: a new ergonomic consumer-oriented Technology for product development. Int. J. Ind. Ergon. 15 (1), 3-11.

Nagamachi, M., Lokman, A.M., 2010. Innovations of Kansei Engineering. CRC Press, Boca Raton, Florida, USA.

Nawab, A., Liu, G., Meng, F., Hao, Y., Zhang, Y., Hu, Y., Casazza, M., 2019. Exploring urban energy-water nexus embodied in domestic and international trade: a case of shanghai. J. Clean. Prod. 23, 522-535.

Norman, D.A., 2004. Emotional Design: Why Do We Love (Or Hate) Everyday Things. Basic Books, New York.

Parasuraman, A., Berry, L.L., Zeithaml, V.A., 1988. SERVQUAL: a multiple-item scale for measuring consumer perceptions of service quality. J. Retailing 64, 12-40.

Rasamoelina, F., Bouchard, C., Aoussat, A., 2013. Towards a Kansei-based user modeling methodology for eco-design. Int J of Affective Eng 12 (2), 337-348.

ReVelle, J.B., 2004. Quality Essentials: A Reference Guide from A to Z. ASQ Quality Press, pp. 90-93.

Rothenberg, S., 2007. Sustainability through servicizing. MIT Sloan Manag. Rev. 48 (2). Winter 2007.

Sakao, T., Lindahl, L., 2009. Introduction to Product/Service-System Design. Springer, Berlin. 
Sakao, T., Birkhofer, H., Panshef, V., Dörsam, E., 2009. An effective and efficient method to design services: empirical study for services by an investment- machine manufacturer. Int. J. Internet Manuf. Serv. 2 (1), 95-110.

Sakao, T., Wasserbaur, R., Mathieux, F., 2019. A methodology approach for manufacturers to enhance value-in-use of service-based offerings considering three dimensions of sustainability. CIRP Ann. - Manuf. Technol. 68, 33-36.

Schütte, S., Eklund, J., Axelsson, J.R.C., Nagamachi, M., 2004. Concepts, methods, and tools in Kansei engineering. Theor. Issues Ergon. Sci. 5, 214-232.

Shih, B.Y., Chen, C.Y., Li, C.E., 2013. The exploration of the mobile Mandarin learning system by the application of TRIZ theory. Comput. Appl. Eng. Educ. 21 (2), 343-348.

Tan, K.C., Pawitra, T.A., 2001. Integrating SERVQUAL and Kano's model into QFD for service excellent development. Manag. Serv, Qual. 11 (6), 418-430.

Tosi, F., 2012. Ergonomics and sustainability in the design of everyday use products. Work, Suppl 1, 3878-3882.
Tukker, A., Tischner, U., 2006. Product-services as a research field: past, present, and future. Reflections from a decade of research. J. Clean. Prod. 14 (17), 1552-1556.

Wolfson, A., Mark, S., Martin, P.M., Tavor, D., 2015. Sustainability through Service: Perspectives, Concepts, and Examples. Springer Briefs in Applied Sciences and Technology. www.bps.go.id. "Statistics Indonesia".

Wong, A., 2004. The role of emotional satisfaction in service encounters. Manag. Serv. Qual. 14 (5), 365-376.

Yang, C.-C., 2011. Identification of customer delight for quality attributes and its applications. Total Qual. Manag. Bus. Excel. 22 (1), 83-98.

Zeithaml, V.A., Bitner, M.J., 2000. Services Marketing: Integrating Customer Focus across the Firm. Irwin/McGraw-Hill, Boston.

Zhang, J., Chai, K.H., Tan, K.C., 2003. 40 Inventive principles with applications in service operations management. The TRIZ J. Dec. Issue. https://triz-journal.com/40inventive-principles-applications-service-operations-management/. 